Prošireni sažetak / Extended abstract

\title{
Dilatative cardiomyopathy
}

\author{
Viktor Peršić* \\ Thalassotherapija Opatija, Opatija, Croatia
}

Dilated cardiomyopathy is a primary myocardial disease of unknown etiology, or the underlying disorders, such as metabolic or infectious origin, and comprises about $90 \%$ of all cardiomyopathies. In dayly clinical practice, given the category of cardiomyopathy often joins ischemic cardiomyopathy, although the current opinions of professional societies omitted.

While the fundamental feature of dilated cardiomyopathy, dilatation and impaired contractility of the heart ventricle in echocardiographic developed from easily recognized, it seems that the causes of disease can hardly be determined only by echocardiography without other clinical tools .

We use echocardiography in the diagnosis of dilated cardiomyopathy using a variety of tools to assess the size and contractility of the heart chambers, and showing the hemodynamic consequences of the disease, The lecture will be presented with echocardiographic methods used in the analysis: two dimensional echocardiography, Doppler echocardiography, and methods for evaluation left ventricular dyssynchrony including strain imaging.

KEYWORDS: dilatative cardiomyopathy, echocardiography.

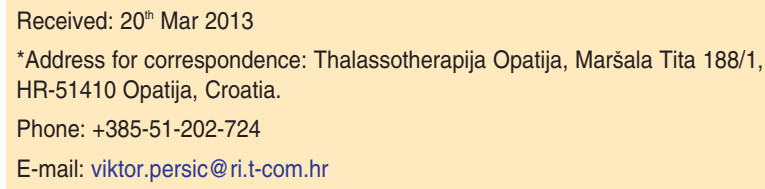

*Address for correspondence: Thalassotherapija Opatija, Maršala Tita 188/1, HR-51410 Opatija, Croatia.

Phone: +385-51-202-724

E-mail: viktor.persic@ri.t-com.hr

\section{Literature}

1. Tigen K, Karaahmet T, Cevik C, Gurel E, Pala S, Mutlu B, et al. Prognostic utility of right ventricular systolic functions assessed by tissue Doppler imaging in dilated cardiomyopathy and its correlation with plasma NT-pro-BNP levels. Congest Heart Fail. 2009;15(5):234-9.

2. Armstrong WF, Ryan T. Feigenbaum's Echocardiography. Philadelphia: Lippincott Williams \& Wilkins, 2009.

3. Cardiac imaging in acquired diseases. In: Brant WE, Helms CA. Fundamentals of Diagnostic Radiology. Philadelphia: Lippincott Williams \& Wilkins, 1998 